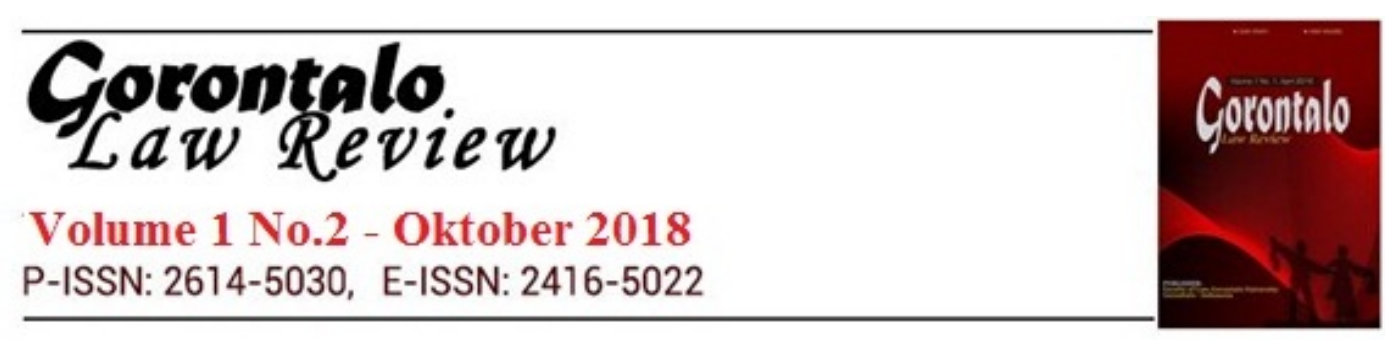

\title{
PERLINDUNGAN HAK WARGA TERHADAP PENEGAKAN HUKUM DI BIDANG KEHUTANAN
}

\author{
Muhammad Zulfan Hakim, \\ M. Yunus Wahid, \\ Hijrah A. Mirzana, \\ Ariani Arifin
}

Fakultas Hukum Universitas Hasanuddin zulfan.unhas@gmail.com

\begin{abstract}
Abstrak
Penegakan hukum lingkungan di bidang kehutanan telah memasuki era baru semenjak diundangkannya beragam peraturan perundangundangan dibidang lingkungan. Semenjak itu, peraturan sektoral di bidang kehutanan juga telah melahirkan banyak ketentuan baru yang tentu saja bersifat memaksa dan menjadi kewajiban bagi aparat penegak hukum. Selain UU Kehutanan No. 41 Tahun 1999, juga ada UU 18 Tahun 2013 tentang P3H. Disisi lain, keberadaan masyarakat yang mendiami kawasan hutan dan telah hidup bahkan jauh sebelum adanya peraturan perundang-undangan di bidang kehutanan telah menimbulkan masalah tersendiri. tulisan ini mencoba untuk menguraikan benturan kepentingan antara warga yang mendiami kawasan hutan dengan pihak aparat penegak hukum terkait penghidupan mereka didalam kawasan hutan yang sudah berlangsung turun-temurun.
\end{abstract}

Kata Kunci : Hutan, perlindungan hutan, penduduk asli

Abstract

Law enforcement in environmental law especially in forestry sector has been living in a new era since the birth of some regulations in environemntal law. Since then, sectoral regulations also emerging and of course this regulations need to be uphold, in order to maintain thefunction of our environment. Beside the Law No. 41/1999 about Forestry, there is also Law No. 18/ 2013 about Prevention and Protection From Forest Destruction. In the other hand, this law are conflicting with the natives that already living in forest area, long before that region stated as a protected forest by the government. This paper tries to explain how to handle such confilct between indigenous people that already living in the forest and the 
law enforcement agent since they have been living their way since long time ago like their anchestors.

Keywords: forest, forest protection, local inhabitants

\section{PENDAHUlUAN}

Hukum lingkungan merupakan salah satu sarana penunjang dalam upaya mewujudkan perlindungan dan pengelolan lingkungan hidup (PPLH) secara optimal. Hukum lingkungan khususnya dalam peraturan perundang-undangan sudah relatif memadai, baik kuantitas maupun kualitasnya, sehingga diharapkan dapat berfungsi dengan baik. Hukum lingkungan yang baik dan relatif lengkap ini, sebagaimana juga hukum pada umumnya, ia tetap dalam dirinya sebagai sarana belaka berupa benda mati belaka. Untuk dapat membawa kebaikan dalam PPLH, hukum lingkungan ini harus dihidupkan dan diterapkan dalam kehidupan nyata oleh manusia. Oleh karena itu, ia memerlukan sejumlah orang yang mau dan mampu menghidupkan, dan menerapkannya dalam kehidupan secara nyata.

Penegakan hukum lingkungan di sektor kehutanan memegang peran penting, baik untuk kegiatan sektor kehutanan sendiri maupun dalam upaya pelestarian fungsi sumber daya alam (SDA) dan lingkungan hidup sebagai tujuan utama PPLH. Hutan sebagai SDA, memiliki fungsi ekonomi, sosial, budaya dan ekologis yang amat penting bagi kehidupan manusia dan makhluk lainnya yang tidak dapat digantikan oleh sumber daya lainnya. Kerusakan dan terganggunya fungsi-fungsi hutan secara langsung berpengaruh terhadap sistem kehidupan, baik ekosistem maupun sosiosistem yang pada gilirannya mengancam kehidupan umat manusia. Oleh karena itu, tidak ada pilihan lain kecuali menjaga dan memelihara kelestarian fungsi-fungsi hutan tersebut, antara lain dengan atau melalui penegakan hukum lingkungan sebagai salah satu sarana penunjang dalam PPLH.

PPLH yang mulai mengemuka dan mendapat perhatian luas pada dekade 70-an, telah banyak membuahkan hasil, baik lokal, nasional maupun internasional. Hal ini ditandai dengan banyaknya peraturan perundang-undangan yang dikeluarkan secara nasional, lokal dan beberapa deklarasi tentang lingkungan hidup. Bagi Indonesia sendiri, masalah lingkungan hidup ini telah ditempatkan secara eksplisit dalam UUD NRI Tahun 1945 sebagai bagian dari Hak Asasi Manusia (Pasal 28H ayat (1) UUD NRI Tahun 1945). Namun demikian, dalam PPLH ini, sungguh masih amat banyak yang harus dilakukan di masa mendatang, di antaranya adalah penegakan hukum lingkungan.

Pada kurun waktu yang bersamaan, masalah dan tantangan yang dihadapi dalam PPLH (UU No. 23 Tahun 1997 (UUPLH)),juga cenderung meningkat baik kualitas maupun kuantitasnya. Masalah muncul susul menyusul termasuk masalah pemanasan global yang kini menjadi perhatian dunia. Semburan lumpur gas, banjir, kekeringan, tanah longsor dan lahan kritis yang tampaknya progresif dengan waktu terdapat di mana-mana. Lahan kritis di Kalimantan misalnya, pada tahun 2000 seluas $7.178 .726 \mathrm{Ha}$ meningkat menjadi 27.918.049 $\mathrm{Ha}$ 
pada tahun 2006 (Kompas, 2009), atau meningkat 4.653.008 Ha pertahun. Adanya kemerosotan hutan secara kuantitas dan kualitas yang progresif dengan waktu menunjukkan bahwa penegakan hukum lingkungan di sektor kehutanan belum berjalan optimal. Penegakan hukum lingkungan dalam arti luas, termasuk di sektor kehutanan merupakan amanat konstitusi bagi penyelenggara negara atau pemerintahan dalam upaya pemenuhan hak atas lingkungan hidup yang baik dan sehat secara berkelanjutan sebagai bagian dari HAM tersebut.

Bersamaan dengan itu, penegakan hukum di bidang kehutanan telah dijalankan oleh pemerintah dengan dikeluarkannya peraturan perundang-undangan sektoral di bidang kehutanan. Selain UU No. 41 Tahun 1999 tentang Kehutanan (selanjutnya UUK), telah dilahirkan pula UU No. 18 Tahun 2013 tentang Pencegahan dan Pemberantasan Perusakan Hutan (selanjutnya disebut UUP3H).

Salah satu hal yang menjadi perhatian terkait penegakan UUP3H tersebut adalah adanya konflik antara peraturan yang menetapkan kawasan hutan dengan warga masyarakat yang telah tinggal dalam kawasan tersebut secara turun-temurun. Hal ini kemudian terbukti ketika pada tanggal 22 Oktober 2017 polisi kehutanan menangkap 3 orang petani yang sedang bergotong royong membersihkan lahan mereka. Ketiga orang ini selanjutnya ditetapkan sebagai tersangka. Kasus pun bergulir ke Pengadilan Negeri Soppeng dan ketiga petani tersebut didakwa melanggar Pasal 83 Ayat (1) dan atau Pasal 12 huruf $b$ atau huruf c Jo. Pasal 82 Ayat (1) huruf a dan/atau huruf b dan/atau huruf c dan Pasal 17 Ayat (2) huruf n Jo. Pasal 92 huruf a Undang-Undang No. 18 tahun 2013 tentang Pencegahan dan Pemberantasan Perusakan Hutan(business-law.binus.ac.id, 2018).

\section{PEMBAHASAN}

Undang-undang Kehutanan telah memberikan definisi mengenai apa yang dimaksud sebagai Hutan dan kawasan hutan. Berdasarkan UUK, Hutan adalah suatu kesatuan ekosistem berupa hamparan lahan berisi sumber daya alam hayati yang didominasi pepohonan daam persekutuan alam lingkungannya, yang satu dan lainnya tidak dapat dipisahkan (Pasal 1 angka 2 UUK). Berdasarkan statusnya terdiri atas hutan negara dan hutan hak. Hutan negara adalah hutan yang berada pada tanah yang tidak dibebani hak atas tanah, hutan hak adalah hutan yang berada pada tanah yang dibebani hak atas tanah. Berdasarkan fungsinya, kawasan hutan negara terdiri atas kawasan hutan lindung, kawan hutan konservasi dan kawasan hutan produksi.

Kawasan hutan, adalah wilayah tertentu yang ditunjuk dan/atau ditetapkan oleh pemerintah untuk dipertahankan keberadaannya sebagai hutan tetap. Dalam rangka memperoleh manfaat yang optimal dari hutan dan kawasan hutan bagi kesejahteraan masyarakat maka pada prinsipnya semua kawasan hutan dapat dimanfaatkan. Pemanfaatan ini tentu saja dengan tetap mempertahankan sifat, karakteristik, dan kerentanannya, serta tidak mengubah fungsi pokoknya (Iskandar,2015).

Dalam perkembangannya, undang-undang kehutanan telah dijalankan sejak tahun 1999 telah menemui sejumlah kendala, sebut 
saja keberadaan hutan adat yang ternyata tumpang tindih dengan penetapan hutan yang dilakukan oleh negara. Kasus lain adalah terjadinya penangkapan warga masyarakat yang diangap melakukan perusakan hutan atau memasuki kawasan hutan yang menurut mereka tidak termasuk kawasan lindung yang dimaksud oleh pemerintah.

Lebih jauh lagi, banyak kejadian kriminalisasi warga yang bermukim di dalam atau berbatasan dengan area hutan bahkan sejak jaman nenek buyutnya. Jauh sebelum penetapan sebagai hutan tetap, mereka telah bermukim di dalamnya dan menggantungkan hidupnya dari hasil hutan seperti hewan buruan, rotan, damar dan kayu. Semuanya hanya untuk memenuhi kebutuhan hidup.

Dalam beberapa kesempatan sosialisasi tentang tapal batas hutan, hal yang banyak dikeluhkan warga adalah penetapan batas hutan yang ternyata mengambil lahan kebun milik warga masyarakat. Tidak dilaksanakannya penelitian yang cukup dalam menentukan tapal batas tersebut telah menimbulkan konflik berkepanjangan antara warga dengan aparat penegak hukum. Andi Arifuddin, kepala Desa Lamatti Riaja Kab. Sinjai yang ditemui penulis menyebutkan bahwa petugas yang melaksanakan pemetaan bahkan tidak mendatangi lokasi yang dimaksud, hanya melihatnya dari kejauhan lalu menetapkan wilayah tertentu sebagaui batas hutan hanya karena terlihat seperti hutan dari kejauhan, padahal jika dilihat lebih dekat, wilayah tersebut ada lahan kebun milik warga.

Penetapan suatu wilayah sebagai kawasan hutan ditetapkan melalui keputusan menteri setelah memalui proses inventarisasi. Berdasarkan UU No. 41 Tahun 1999:

Pasal 13

(1) Inventarisasi hutan dilaksanakan untuk mengetahui dan memperoleh data dan informasi tentang sumber daya, potensi kekayaan alam hutan, serta lingkungannya secara lengkap.

(2) Inventarisasi hutan sebagaimana dimaksud pada ayat (1) dilakukan dengan survei mengenai status dan keadaan fisik hutan, flora dan fauna, sumber daya manusia, serta kondisi sosial masyarakat di dalam dan di sekitar hutan.

(3) Inventarisasi hutan sebagaimana dimaksud pada ayat (2) terdiri dari:

a. inventarisasi hutan tingkat nasional,

b. inventarisasi hutan tingkat wilayah,

c. inventarisasi hutan tingkat daerah aliran sungai, dan

d. inventarisasi hutan tingkat unit pengelolaan.

(4) Hasil inventarisasi hutan sebagaimana dimaksud pada ayat (1), ayat (2), dan ayat (3) antara lain dipergunakan sebagai dasar pengukuhan kawasan hutan, penyusunan neraca sumber daya hutan, penyusunan rencana kehutanan, dan sistem informasi kehutanan.

(5) Ketentuan lebih lanjut sebagaimana dimaksud pada ayat (1), ayat (2), dan ayat (3) diatur dengan Peraturan Pemerintah.

Selanjutnya dalam pasal 14

(1) Berdasarkan inventarisasi hutan sebagaimana dimaksud dalam Pasal 13, pemerintah menyelenggarakan pengukuhan kawasan hutan. 
(2) Kegiatan pengukuhan kawasan hutan sebagaimana dimaksud pada ayat (1), dilakukan untuk memberikan kepastian hukum atas kawasan hutan

Pasal 15 :

(1) Pengukuhan kawasan hutan sebagaimana dimaksud dalam pasal 14 dilakukan melalui proses sebagai berikut :
a. Penunjukan kawasan hutan
b. Penataan batas kawasan hutan
c. Pemetaan kawasan hutan dan
d. Penetapan kawasan hutan

(2) mengukuhan kawasan hutan sebagaimana dimaksud pada ayat (1) dilakukan dengan memperhatikan rencana tata ruang wilayah proses pengukuhan inilah yang kadang tidak dilaksanakan dengan teliti sehingga batas hutan yang ditetapkan kemudian bersinggungan dengan lahan kebun yang dimiliki dan dikelola oleh warga sekitar. Salah seorang warga yang ikut serta dalam kegiatan sosialisasi yang dilaksanakan menyebutkan bahwa bukan warga yang merambah kawasan hutan tapi hutan yang merambah lahan milik warga.

CONTOH KASUS

Salah satu kasus yang terjadi terkait terjadinya penangkapan tiga orang warga masyarakat yang dituduh melakukan perusakan terhadap hutan di kawasan hutan Laposo Niniconang Kabupaten Soppeng Propinsi Sulawesi Selatan. Tuduhan yang diberikan adalah perbuatan mereka melanggar Pasal 83 Ayat (1) dan atau Pasal 12 huruf b atau huruf c Jo. Pasal 82 Ayat (1) huruf a dan/atau huruf b dan/atau huruf c dan Pasal 17 Ayat (2) huruf n Jo. Pasal 92 huruf a Undang-Undang No. 18 Tahun 2013 tentang Pencegahan dan Pemberantasan Pengerusakan Hutan (P3H). Ketiganya adalah Jamak Bin Kadu (45 Tahun), Sdukardi Bin Massalese (39 Tahun), dan Muhammad Sahidi Bin Kadire (47 Tahun), ketiganya adalah petani yang ditangkap pada tanggal 25 Oktober 2017,

Kasus ini bermula ketika ketiganya bersama sejumlah warga lain didapati oleh petugas patroli Tim Gabungan yang terdiri dari Gakkum wilayah Sulawesi, Polres Soppeng, Kodim 1426 Soppeng, Staf BPKH wilayah VII dan Polhut Dinas Kehutanan Propinsi Sulsel, sedang melakukan penanaman jahe dalam kawasan hutan.

Mereka yang ditangkap berasal dari kampung Cappoliang dan kampung Jolle, desa Umpungeng, Kecamatan Lalabata kab Soppeng. Mereka telah hidup secara turun temurun dalam kawasan hutan Laposo Niniconang. Ketiganya didakwa telah melakukan perusakan hutan sesuai Pasal 12 huruf b Jo Pasal 82 ayat (1) huruf a UU No 18 Tahun 2013 tentang P3H. Para petani tersebut dituduh telah melakukan perusakan terhadap hutan tanpa izin dari pihak yang berwenang sementara warga yang ditangkap merasa bahwa lahan tersebut adalah lahan milik neneknya dahulu.

Jika mengacu pada UU No. 41 Tahun 1999 tentang Kehutanan dijelaskan pada pasal 3 bahwa prinsip penyelenggaraan hutan itu harus bertujuan untuk sebesar-besar kemakmuran rakyat yang berkeadilan dan berkelanjutan dengan : 
a. Menjamin keberadaan hutan dengan luasan yang cukup dan sebaran yang proporsional

b. Mengoptimalkan aneka fungsi hutan yang meliputi fungsi konservasi, fungsi lindung, dan fungsdi produksi untuk mencapai manfaat lingkungan, sosial, budaya, dan ekonomi yang seimbang dan lestari;

c. Meningkatkan daya dukung aliran sungai

d. Meningkatkan kemampuan untuk mengembangkan kapasitas keberdayaan masyarakat secara partisipatif, berkeadilan, dan berwawasan lingkungan sehingga mampu menciptakan ketahanan sosial dan ekonomi serta ketahanan terhadap perubahan eksternal; dan

e. Menjamin distribusi manfat yang berkeadilan dan berkelanjutan.

Selanjutnya dalam Pasal 12 huruf b Jo Pasal 82 ayat (1) huruf a UU No 18 Tahun 2013 tentang P3H disebutkan bahwa :

Pasal 12

Setiap orang dilarang

a. Melakukan penebangan pohon dalam kawasan hutan yang tidak sesuai dengan izin pemanfaatan hutan;

b. Melakukan penebangan pohon dalam kawasan hutan tanpa memiliki izin yang dikeluarkan oleh pejabat yang berwenang.

c. Melakukan penebangan pohon dalam kawasan hutan secara tidak sah.

d. Memuat membongkar mengeluarkan mengangkut mengeluarkan menguasai dan/atau memiliki hasil penebangandi kawasan hutan tanpa izin.

e. Mengangkut, menguasai atau memiliki hasil hutan kayu yang tidak dilengkapi secara bersama surat keterangan sahnya hasil hutan

f. Membawa alat-alat yang lazim digunakan untuk menebang, memotong atau membelah pohon didalam kawasan hutan tanpa izin pejabat yang berwenang

g. Membawa alat-alat berat dan atau alat-alat lainnya yang lazim atau patut diduga akan digunakan untuk mengangkut hasil hutan dalam kawasan hutan tanpa izin pejabat yang berwenang

h. Memanfaatkan hasil hutan kayu yang diduga berasal dari pembalakan liar

i. Mengedarkan kayu hasil pembalakan liar melalui perairan, darat atau udara

j. menyelundupkan kayu yang berasal dari atau masuk ke wilayah Negara Kesatuan Republik Indonesia melalui sungai, darat, laut, atau udara;

k. menerima, membeli, menjual, menerima tukar, menerima titipan, dan/atau memiliki hasil hutan yang diketahui berasal dari pembalakan liar;

1. membeli, memasarkan, dan/atau mengolah hasil hutan kayu yang berasal dari kawasan hutan yang diambil atau dipungut secara tidak sah; dan/atau

m. menerima, menjual, menerima tukar, menerima titipan, menyimpan, 
dan/atau memiliki hasil hutan kayu yang berasal dari kawasan

hutan yang diambil atau dipungut secara tidak sah.

Selanjutnya dalam pasal 82 ayat (1):

Orang perseorangan yang dengan sengaja :

a. Melakukan penebangan pohon dalam kawasan hutan yang tidak sesuai dengan izin pemanfaatan hutan sebagaimana yang dimaksud dalampasal 12 huruf a

b. Melakukan penebangan pohon dalam kawasan hutan tanpa memiliki izin yang dikeluarkan oleh pejabat yang berwenang sebagaimana dimaksud pasal 12 huruf b

c. Melakukan penebangan pohon dalam kawasan hutan secara tidak sah sebagaimana dimaksud dalam Pasal 12 huruf c

Dipidana dengan pidana penjara paling singkat 1 (satu) tahun dan paling lama 5 (lima) tahun dan pidana denda paling sedikit 500.000.000,- (Lima Ratus Juta Rupiah) dan paling banyak Rp.

2.500.000 000,- (Dua Milyar Lima Ratus Juta Rupiah)

Selanjutnya dalam pasal 82

Dalam hal tindak pidana dimaksud dalam ayat (1) diolakukan oleh orang perseorangan yang bertempat tinggal di dalam dan/atau di sekitar kawasan hutan, pelaku dipidana dengan pidana penjara paling singkat 3 (tiga) bulan dan paling lama 2 (dua) tahun dan atau pidana denda paling sedikit Rp. 500.000 (lima ratus ribu rupiah) dan paling banyak Rp. 500.000.000 (lima ratus juta rupiah).

Berdasarkan ketentuan tersebut, maka pihak polisi hutan yang melakukan penangkapan kemudian mengambil tindakan dengan menahan para petani tersebut, dengan tuduhan melakukan kegiatan tanpa izin dalam kawasan hutan lindung Niniconang Kecamatan Lalabata Kab. Soppeng Propinsi Sulawesi Selatan yang ditetapkan melalui Keputusan Menteri Kehutanan RI No. SK 5536/MENHUTVII/KUH/2014 tanggal 2 September 2014.

Penahanan dilakukan dengan rincian

a. Penahanan oleh penyidik sejak 25 Oktober 2017 Sampai 13 November 2017

b. Penyidik perpanjangan oleh Penuntut umum sejak 14 November 2017 sampai 23 Desember 2017

c. Penyidik Perpanjangan pertama oleh ketua pengadilan negeri 24 Desember 2017 sampai dengan 24 Januari 2018

d. Penuntut Umum sejak tanggal 18 Januari 2018 sampai dengan 6 Februari 2018

e. Hakim Pengadilan Negeri sejak 25 Januari 2018 sampai dengan 23 Februari 2018

f. Hakim Pengadilan Negeri Perpanjangan oleh Ketua Pengadilan Negeri sejak 24 Februari 2018 sampai dengan 24 April 2018.

Dalam pemeriksaan perkara di pengadilan, semua saksi-saksi membenarkan baahwa para tersangka memang melakukan kegiatan di dalam kawasan hutan tersebut. Sejalan dengan hal tersebut, pihak polisi hutan juga dalam keterangannya membenarkan bahwa para terdakwa telah melakukan perusakan antara lain dengan menebang pohon untuk 
dijadikan rumah kebun. Penebangan juga dilakukan untuk menghilangkan pohon yang dapat menghalangi cahaya matahari bagi tanaman cengkeh, kopi atau jahe yang ditanam oleh para terdakwa.

Dalam pandangan para penasihat hukum para terdakwa dari LBH Makassar, pihak polisi hutan telah memberlakukan peraturan yang keliru terhadap para petani tersebut. Bahwa penyelenggaraan hutan adalah ditujukan untuk sebesar-besar kemakmuran rakyat dengan memperhatikan Pasal 3 UU No. 41 Tahun 1999 Tentang Kehutanan, sehingga warga masyarakat yang melakukan pemanfaatan tersebut tidak dapat dipandang sebagi melakukan perusakan.

Apa yang dilakukan oleh para terdakwa murni hanya melakukan upaya cocok tanam tanpa berniat melakukan perusakan hutan seperti yang dituduhkan oleh pihak penegak hukum.

Dalam tuntutannya, pihak Jaksa dalam dakwaannya menyebutkan bahwa para terdakwa telah memenuhi unsur-unsur yang tercantum dalam UU 182003 yang antara lain:

a. Memenuhi unsur setiap orang

b. Memenuhi unsur dengan sengaja melakukan penebangan pohon dalam kawasan hutan tanpa memiliki izin yang dikeluarkan oleh pejabat yang berwenang

Pengertian "setiap orang" dalam UU No. 18 Tahun 2013 tentang $\mathrm{P} 3 \mathrm{H}$ tersebut memiliki pengertian yang bersifat khusus (specialis) yang berbeda dengan ketentuan "setiap orang" dalam peraturan perundangundangan pada umumnya.

Pengertian setiap orang yang dimaksud dalam UU 18 Tahun 2003 adalah perseorangan dan atau korporasi yang melakukan perbuatan perusakan hutan secara terorganisasi di wilayah Indonesia dan/atau berakibat hukum di wilayah hukum Indonesia.

Pertimbangan selanjutnya bahwa yang dimaksud perusakan hutan berdasarkan Pasal 1 angka 3 UU 182013 adalah proses atau cara atau perbuatan merusak hutan melalui kegiatan pembalakan liar, penggunaan kawasan hutan tanpa izin atau penggunaan izin yang bertentangan dengan maksud dan tujuan pemberian izin didalam kawasan hutan yang telah ditetapkan.

Penggunaan kawasan hutan secara tidak sah yang dimaksud dalam ketentuan perundang-undangan No. 18 Tahun 201 menegaskan sebagai "sebuah kegiatan terorganisasi yang dilakukan dalam kawasan hutan untuk perkebunan dan/atau pertambangan tanpa izin menteri.

Selanjutnya, berdasarkan keterangan danpemeriksaan terdakwa bahwa memang dia tidak memliki bukti kepemilikan apapun terkait lahan tersebut, hanya berpegang pada pengetahuannya bahwa lahan tersebut dulunya adalah milik neneknya. Terdakwa melakukan penebangan pohon menggunakan parang untuk menghilangkan penghalan cahaya matahari bagi tanaman jahe dan kopi yang ditanamnya dalam lokasi tersebut yang berukuran kurang lebih 0,6 Ha.

Pada prinsipnya, pembelaan pihak terdakwa selalu menekankan pada tidak sesuainya penggunaan peraturan UU P3H tersebut untuk digunakan dalam dakwaan pada kasus terkait. 
Hal ini sesuai dengan kondisi-kondisi yang telah lebih dahulu disebutkan diatas.

Selain itu dalam keterawngannya, ahli Ahmad Sofian (Jamak Bin Kaddu Dkk) akademisi yang diajukan ke pengadilan sebagai saksi ahli dari para terdakwa menjelaskan bahwa terdapat kesalahan ketika jaksa penuntut menggunakan Pasal 12 huruf b Jo Pasal 82 ayat (1) huruf a UU No 18 Tahun 2013tersebut kepada terdakwa.

Pertama, bahwa adanya lingkungan yang rusak dan pembalakan hutan lindung dan mengatasi kejahatan untuk sektor kehutanan maka dibentuk UU No. 18 Tahun 2003 karena UU sebelumnya tidak mampu mengatasi kejahatan kehutanan yang terorganisir.

Selanjutnya menurut keterangan ahli, mengenai pasal 12 huruf $b$ dan huruf c Jo. Pasal 82 Ayat (1) huruf a dan huruf c dan pasal 17 ayat (2) huruf b Jo. Pasal 92 ayat (1) huruf a UU P3H tersebut sebagaimana yang didakwakan kepada terdakwa tidak dapat dilihat secara parsial, melainkan harus dilihat dari filosofi atau prinsip dasar yang yang terkandung dalam UU P3H tersebut secara utuh.

Prinsip dasar tersebut terletak pada Pasal 1 yang berisi ketentuan umum, asas-asas

Dari UU P3H.

Pasal 1 angka 3

Perusakan hutan adalah proses, cara, atau perbuatan merusak hutan melalui kegiatan pembalakan liar, penggunaan kawasan hutan tanpa izin atau penggunaan izin yang bertentangan dengan maksud dan tujuan pemberian izin di dalam kawasan hutan yang telah ditetapkan, yang telah ditunjuk, ataupun yang sedang diproses penetapannya oleh Pemerintah.

Pasal 1 Angka 4

Pembalakan liar adalah semua kegiatan pemanfaatan hasil hutan kayu secara tidak sah yang terorganisasi.

Pasal 1 Angka 6

Terorganisasi adalah kegiatan yang dilakukan oleh suatu kelompok yang terstruktur, yang terdiri atas 2 (dua) orang atau lebih, dan yang bertindak secara bersama-sama pada waktu tertentu dengan tujuan melakukan perusakan hutan, tidak termasuk kelompok masyarakat yang tinggal di dalam atau di sekitar kawasan hutan yang melakukan perladangan tradisional dan/atau melakukan penebangan kayu untuk keperluan sendiri dan tidak untuk tujuan komersial.

Pasal 1 Angka 21

Setiap orang adalah orang perseorangan dan/atau korporasi yang melakukan perbuatan perusakan hutan secara terorganisasi di wilayah hukum Indonesia dan/atau berakibat hukum di wilayah hukum Indonesia.

Pada pasal 1 anka 3,4,6 dan 21 maka terlihat bahwa dari pasal 1 Angka 6 mengandung imunitas bagi kelompok masyarakat yang tinggal atau bermukim didalam atau sekitar kawasan yang melakukan perladangan tradisional dan atau menebang kayu untuk kebutuhan 
sendiri dan tidak untuk tujuan komersial dan bahwa UUP3H dibuat untuk memberantas kejahatan korporasi atau kejahatan yang terorganisir.

Lebih lanjut, dalam keterangannya juga ahli menjelaskan maksud dari korporasi adalah dilakukan secara berkelompok dengan organisasi yang sitematis, dan itu tidak sesuai dengan penduduk yang bermukim di dalam atau sekitar kawasan hutan.

Jika ditinjau dari aspek illegal loging, maka apa yang dilakukan oleh para terdakwa tersebut juga toidak termasuk illegal logging karena tidak adanya kerjasama yang besar untuk melakukan penebangan dan menjual belikan hasil tebangan tersbut. Parqa terdakwa dalam kasus ini hanya satu-dua orang dan tidak ada yang membeli atau menjual hasil tebangan pohon seperti yang didakwakan oleh penuntut.

\section{PENUTUP}

\section{Kesimpulan}

Berdasarkan hasil pembahasan yang telah disampaikan sebelumnya, maka dapat disimpulkan bebrapa hal antara lain Pengalihan kewenangan di bidang kehutanan kepada pemerintah provinsi juga dianggap menjadi faktor yang mempengaruhi kinerja pemerintah kabupaten dalam melaksanakan pengawasan dan perlindungan kawasn hutan.

Penetapan batas hutan harus dilakukan melalui penelitian yang mendalam terutama mengenai adanya warga masyarakat yang telah lebih dahulu memanfaatkan kawasan tersebut sebagai kebun dan Perlu digalakkan sosialisasi yang lebih baik dan lebih banyak utamanya kepada warga yang bermukim di sekitar kawasan hutan agar tidak lagi terjadi kriminalisasi

\section{DAFTAR PUSTAKA}

Abdul Muis Yusuf, Taufik Makaro, Hukum Kehutanan di Indonesia, Rineka Cipta Jakarta, 2011

Alam Setia Zain, Hukum Lingkungan Konservasi Hutan bdan Segi-segi Pidana, Rineka Cipta, Jakarta 2000

Iskandar, Hukum kehutanan, Madar Maju Bandung cetakan ke I Maret 2015

Muhammad Yunus Wahid, Hukum Lingkungan, Mandar Maju, Jakarta 2011

Wartiningsih, Pidana Kehutanan, Setara Press, Malang, 2014

UU No. 41 Tahun 1999 Tentang Kehutanan

UU No. 18 Tahun 2003 Tentang Perlindungan Perusakan Hutan

http:// business-law.binus.ac.id/2018/03/30/tafsir-atas-subjek-delik-

perusakan-hutan-dalam-uu-p3h/

http://www.negarahukum.com/hukum/tirani-penetapan-kawasan-

hutan.html 